\title{
Investigating The Use of Modal Auxiliary Verbs in Tempo Editorial
}

\author{
'AZKA SAEFUL HAQ, ${ }^{2}$ SUTIONO MAHDI \\ IUniversitasPadjadjaran, 2UniversitasPadjadjaran \\ 'azka1900I@mail.unpad.ac.id, ${ }^{2}$ sutiono.mahdi@unpad.ac.id
}

\begin{abstract}
Editorial texts provide opinions to influence publics toward actual issues in society. The opinions contain critics served in suitable dictions and argumentations to access wider comprehension toward reality. Government policyissue in this research is provided to trace the preference of Tempo in serving its own tendency. This research aims to investigate frequency of modal auxiliary verbs in Tempo editorial and the meaning of the frequency which furthermore reflect Tempo strategy in delivering its own news. The method used in this research is descriptive qualitative that employs sampling technique to gain selected data. The data is collected from online Tempo editorial text with the similar national issue and categorized into major types of modal auxiliary verb. The researcher only chooses 9 texts in November 2019 because of their relevance in a topic each other. The result consists of 104 data that is divided into three major types of modal auxiliary verb function, namely prediction, necessity, and probability.
\end{abstract}

Keywords: Modal Auxiliary Verb, Editorial, Prediction, Necessity, Probability

\section{INTRODUCTION}

Editorial texts certainly do not aim to give the opinions only, they convey the effect of phenomena informed to social world in news as well.They have crucial role in influencing society towards an actual issue that will be broadly consumed by public. Controversial or influential issue in society is usually chosen to attract readers because they do intervene to readers' world to live their life. They try to persuade the readers to have the similar perspective as the they do because readers mediated by media with its data cannot access the reality directly. Reality also cannot explain itself to people in any interaction without signs and language as the main tools to acquire kinds of knowledge. In persuading people, editorial texts are served in certain dictions and argumentations as some of the strategies.

Complex idea needs to be conveyed through using complex sentences. Structure of sentences do not only represent the meaning of the words but also the purposes of writers. Content of editorial presents measured opinions with arranging suitable words. Perspective of writer can be revealed through observating the structure of sentences. The use of modal auxiliary reflects consideration of writer in serving his opinions. The opinions of editorials can be supporting or critics to the phenomenon so that readers can 
comprehend selectively the tendency of writers in acquiring the informations. The structure and dictions are certainly constructed to elaborate argumentations.

Considering every meaning of auxiliary verbs can increase readers' comprehension of writer's understanding towards issues to describe and predict through using linguistic features. It can be useful for readers to evaluate editorial writers' attitude that will be cited to be input of information. The perception of reality and the attitude toward issues are the result of serving opinions that readers will decide after reading editorials. The input of opinions from editorials consumed should be filtered firstly to assure the background of information.

One of the previous related studies is from Bonyadi (2011) entitled Linguistic Manifestations of Modality in NewspaperEditorials which presents modality of two newspaper editorials compared. The second study is a paper of Sujatna and Kasno (2019) entitled Exploring The Use Of Modal Auxiliary VerbsIn Corpus Of Contemporary Of American English (COCA)that provides frequency of modal auxiliary use and its patterns. The third study is from Gustilo (2011) entitled Modal Auxiliaries in Philippine English Newspapers: a Corpus-basedAnalysis that reflects the frequency of auxiliary verbs as well. Thispresent researchaims to investigate frequency of modal auxiliary verbs in Tempo editorial and the meaning of the frequency. It is different with previous research that this present research provides diffrent issue, particularly government policy issue, to explicate editorial's preference. To acquire different significance, this present research focuses only to Tempo editorials presenting its tendency in presenting news because Tempo emerges as one of huge news media in Indonesia.

\section{Auxiliary Verbs}

Verbs in English is not only explained as one of syntactic category, but also as surface structure that is similar with subject and object. Verbs in this context refer to main verb and auxiliary verb as two types of verb in English structure. Febb (2005) states that the main verb is always the final (rightmost) verb in thesequence if there is only one verb, it will almost always be the mainverb in English. A complicating fact is that the words $d o$, have and be exist both asauxiliary and as main verbs. In using an auxiliary verb, the main verb position moves after the auxiliary verb emerges.

Biber (2003) remarks that auxiliary verbs occur before a main verb and qualify the meaning of the main verb.It is not smae with the mainverb, auxiliary verb does not have a lexical meaning. That is the reason whyauxiliary verbs are also calledhelping verbs in a sentence. English auxiliary verbs are basically divided into primary auxiliary verbs andmodal auxiliary verbs. As table 1 below, a sentence can contain modal auxiliary, primary auxiliary, and main verb in grammatically correct position. 
Table 1. auxiliary verb position in a sentence (Febb, 2005)

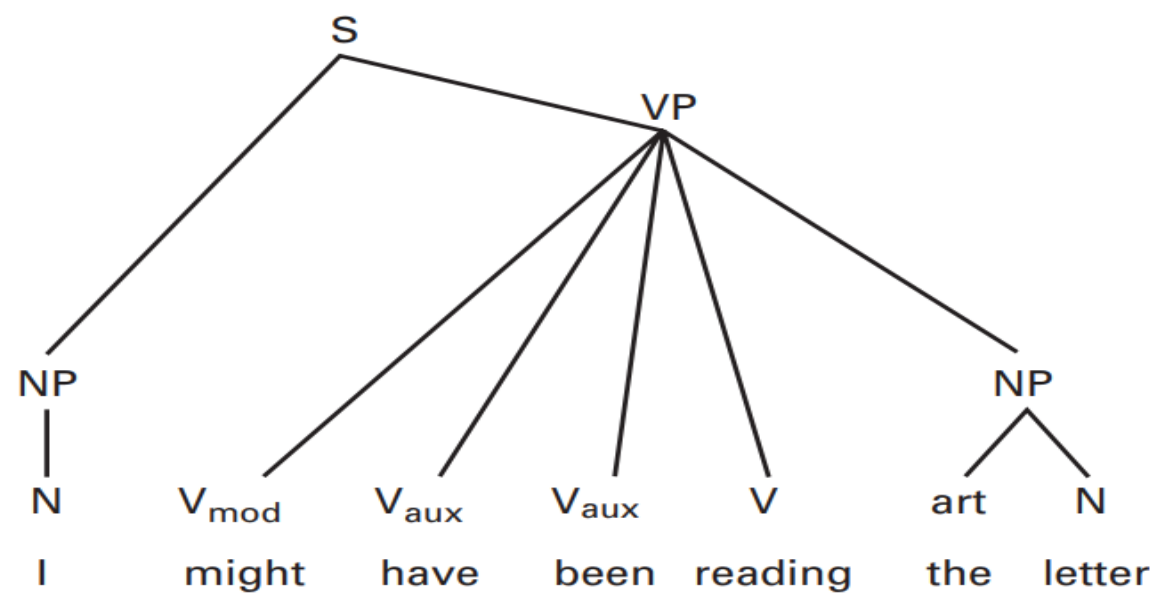

\section{Primary Auxiliary Verb}

This kind of verb refers to complementary verb to assure the meaning of a sentence. Biber (2003) states that primary verbs can function as both auxiliary and main verbs. Primary auxiliary is a group of complementary verb that has noa meanings but it helps to construct tenses characteristics. Primary auxiliary verbsconsist of do, to be and have but those verbs can be considered as primary auxiliary verb if they are used as main verb in a sentence.

\section{Modal Auxiliary Verb}

Modal auxiliary verbsare the verbs that appear before the main verb tomodify the meaning of main verb. To expresswillingness, ability, possibility and necessity are the aims to use modal auxiliary verbs. Unlikeprimary auxiliary verbs which can stand alone in a sentence as the main verbs do, modal auxiliaryverbs must grammatically be followed by the main verbs. Modal auxiliary verbs consist of can, could, shall, should, will, would, may, might, and must. There are three types of funcion delivered by groups of modal verb.

\section{Can and Could}

The modal verb can conveys the ability, permission, and theoretical possibility based on the context in a sentence. The modal verb could is employed to convey the same function as the verb can but it emerges in past tenses.

\section{Will and Would}

The verbs will and would are used to state willingness, intention, and prediction. The verb would can be used to express insistence, it is rather rare and with a strong stress on the word. 


\section{May and Might}

The verbs may and might are used in the context of granting or seeking permission but the difference is in the past tense for the verb might. The verb might is considerably more tentative than the verb may.

\section{METHOD}

The method used in this research is descriptive qualitative that deals with argumentative words and the researcher as the instrument. It employs sampling technique to gain selected data collected from online Tempo editorial text with the similar national issue and they are categorized into major types of modal auxiliary verb. The researcher only chooses 9 texts in November 2019 because of their relevance in a topic each other.In the first step, the researcher gains the script and divides it into sentences as data. The second step, modal auxiliary is categorized into different function. The third step, frequency of modal auxiliary use will be served and meant as the last procedure.

\section{FINDINGS AND DISCUSSION}

Findings consist of 104 data that are divided into three major types of modal auxiliary verb function, namely prediction, necessity, and probability but in this research the findings served are only the sample because of its numerous quantities. The linguistic evidences are only served in sample for each type.To avoid bias interpretation, the researcher conducts systematic random sampling through focusing firstly on type of modal auxiliaries. The interpretation will be provided after serving the data and finding the frequency. The frequency of data is calculated for the preference of Tempo editorials in delivering the news will be acquired. There are seven types of modal auxiliary verbs categorized into three kind of functions in Tempo editorial.

\section{A. Prediction}

Prediction functions to inform the effect of phenomena which is discussed in editorial. This function provides the verbs will and would that were collected from Tempo editorial in November 2019. The verb will is used 32 times and the verb would is used 9 times. These are the samples of sentences.

\section{Will}

- Our economy will always need the support of the private

- Reciprocal arrangements between officials and mass organizations like this will damage democracy and local governance.

- If it goes ahead, this plan will worsen environmental damage and reduce the suitability and safety of buildings.

\section{Would}

- It was hoped that the building of infrastructure, especially the Trans Papuan Highway, would reduce income inequality and spark growth. 
- The economy would suffer a shock if they all decided to relinquish their investments.

- Therefore, it would be truly surprising if the government did not evaluate this policy and seek better alternative solutions.

\section{B. Necessity}

Necessity functions to convey what the priorities are. This function provides the verbs must and should that were collected from Tempo editorial in November 2019. The verb must is used 27 times and the verb should is used 13 times. These are the samples of sentences.

\section{Must}

- Once again, the resolution of the protracted conflict in Papua must start from the roots.

- The government must take this into consideration.

- As well as ability in a professional sense, the leaders of SOEs must have good track records.

\section{Should}

- Minister for State-Owned Enterprises (SOEs) Erick Thohirshould think again about the scheme to rescue AsuransiJiwasraya, which was planned by his predecessor.

- He should also stop the politics of patronage that gives special treatment to individuals or organizations.

- Aniesshould not blame the system used by his administration.

\section{Possibility}

Possibility functions to inform the consequence of an act discussed in editorial. This function provides the verbs could, might and can that were collected from Tempo editorial in november 2019. The verb could is used 16 times, the verb can is used 6 times and the verb might is used once. These are the samples of sentences.

\section{Could}

- The Bekasi mayor should realize that involving mass organizations identified with thuggery in parking management could become a boomerang.

- Anies justification for this is that publication could cause conflict.

- This audit could follow up on the findings of the Supreme Audit Agency (BPK).

6. Can

- The obligation to produce an environmental impact analysis can be bypassed.

- The best way to solve the problem of Papua can only be achieved through dialogue.

- Our economy will always need the support of the private sector so that it can stay strong and flourish.

\section{Might}

- This policy might satisfy a small number of elite. 
Table 2. Frequency of modal auxiliary verbs in Tempo editorial

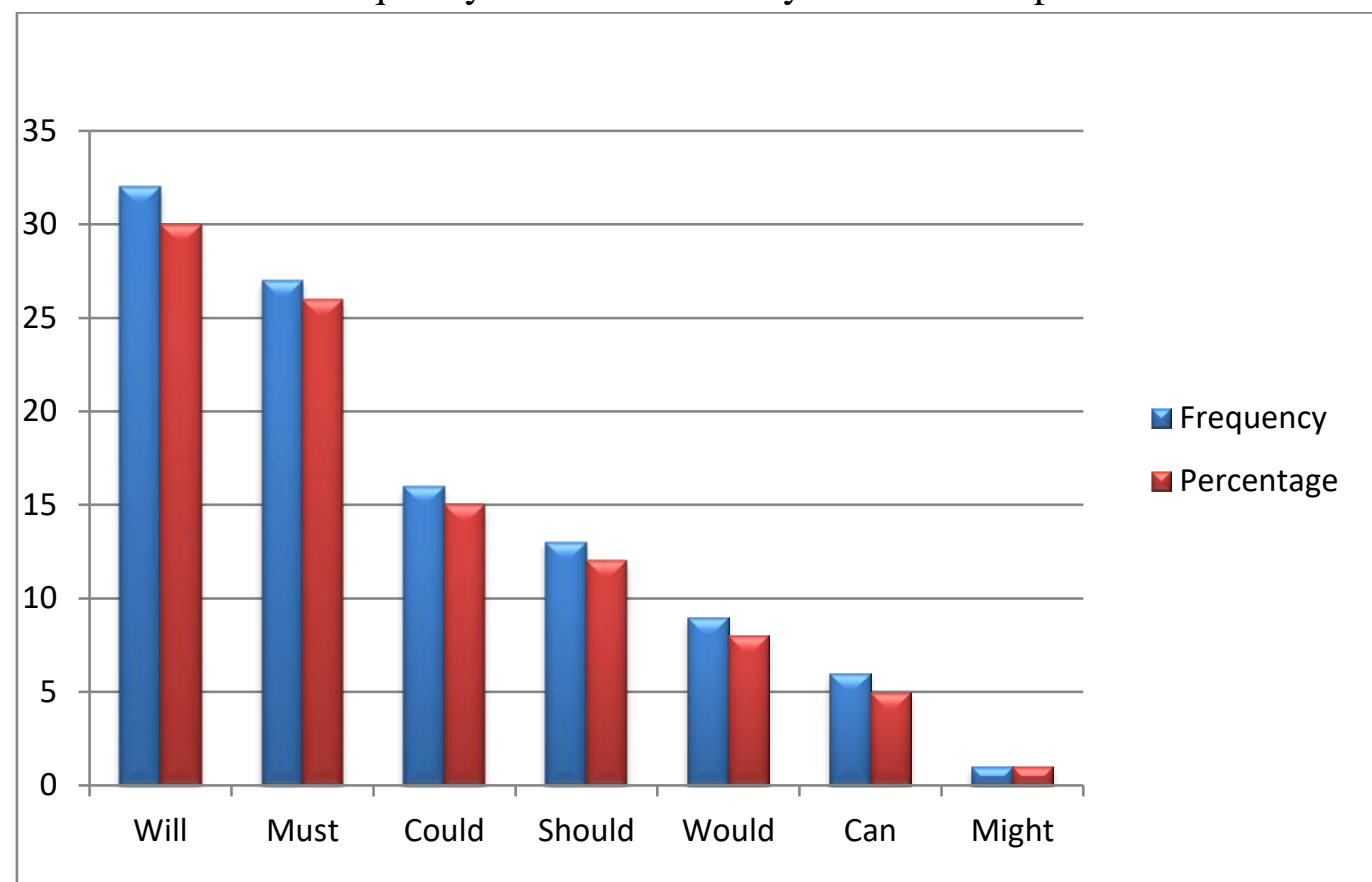

The table informed by chart shows that the modal verb will has the biggest proportion in Tempo editorial. It emerges 32 times and takes $30 \%$ in total of frequency. The second most dominant modal verb is must that takes $26 \%$ in proportion. The third most dominant modal verb is could which takes $15,4 \%$ in proportion. Their position are followed by the other modal verb such as should $12,6 \%$, would $8.6 \%$, can $5,8 \%$, and might $0,96 \%$ in proportion. Tempo editorials tend to provide the risk of a policy through using the verb will predominatly. It means Tempo editorial prefers to persuade readers to consider the risk of policy in its news. The use of must as one of frequentative auxiliary shows that Tempo tends to give solution toward issue discussed. Those are the analysis of Tempo editorial patterns which are regular and predictable.

\section{CONCLUSION}

Types of modal auxiliary verb used in Tempo editorial are will, must, could, should, would, can, and might. The most dominant modal verb will represents the writer's purpose in conveying the opinions toward the readers. It indicates that the writer mostly serves predictable effect in his opinion as in the sentence "reciprocal arrangements between officials and mass organizations like this will damage democracy and local governance." The sentence contains causal message to warn the goverment in executing the policy. The preference of will and must verbs explicates that Tempo editorials tend to persuade readers to think the risk and solution in an issue. That kind of critic is aimed to 
stimulate public in answering the issues and the writers try to increase public awareness. This reserach can be applied to increase reader's awareness in choosing media editorials and considering its choice to acquire more benefit opinions. The researcher suggests to do similar research with different issue in various object such as po;itical speech or diplomatic discourse for further research.

\section{References}

Anderson, GDS. (2011). Auxiliary Verb Constructions (and other complex preditace types) : A functional Construal Overview. Language and Linguistics Compass.

Anwar, B., Butt, B., and Khan, RMI. (2019). Modal Auxiliaries in Pakistani English Newspapers: Social and Pedadogical Perspectives.

Arslanov, VSD and Tarasova, AN.(2016). New Look upon the Grammatical Functions of some English Modal Auxiliaries and Semi-modals Expressing Obligation and Necessity. International Journal of Humanities and Cultural Studies.

Ayoun, D and Gilbert, C.(2017).Tense-Aspect-Modality in a Second Language. Contemporary Perspectives.

Biber, D., Conrad, S., and Leech, G. (2002). Longman Grammar of Spoken and Written English.London:Longman.

Bonyadi, Alireza. (2011). Linguistic Manifestations of Modality in NewspaperEditorials Urmia BranchIslamic Azad University

Dede, K.(2016).Modal Auxiliaries in Qinghai Chinese. New Horizons in the Study of Chinese: Dialectology, Grsmmsr, and Philology.

Febb,Nigel. (2005). Sentence Structure Second Edition. Routledge: USA

Gustilo, Leah Espada. (2011). Modal Auxiliaries in Philippine English Newspapers: a Corpus-basedAnalysis. Philippine ESL Journal, Vol. 6.De La Salle University: Manila.

Hardjanto, TD.(2016).Hedging through the Use of Modal Auxiliaries in English Academic Discourse. Jurnal Humaniora 28 (1)

Lumanda, LT.(2019). A LinguisticView on the Use of Will and Shall as Auxiliaries or Inflections. Communication and Linguistics Studies 5 (1)

Octavita, AI.(2017).The Equivalence of English Modal Auxiliaries into Indonesian. DEIKSIS 9 (02). 
Sasaki, A.(2018).The Use of Modal Auxiliaries in Pride and Prejudice. Hiroshima Studies in English Language and Literature.

Silviana, Ruth, and Surbakti.(2016). An Analysis of Auxiliary Verb andConjucntions Used in The Jakarta Post Newspaper. RepositorilnstitusiUSU.

Smutná,Zdeňka. (2010). The Use of the Modal Verb Can in Newspaper Reporting.University of Pardubice.

Sujatna, Meita,Sujatna, Eva Tuckyta,and Pamungkas, Kasno. (2019). Exploring The Use Of Modal Auxiliary VerbsIn Corpus Of Contemporary Of American English (COCA). 